\title{
THE PATENTABILITY OF MAORI TRADITIONAL MEDICINE AND THE MORALITY EXCLUSION IN THE PATENTS ACT 1953
}

\author{
Susan Young*
}

Many indigenous peoples, including Maori, are offended by third parties 'appropriating' their traditional knowledge by means of intellectual property rights, such as patents.

The author first surveys international debate about indigenous intellectual property rights in connection with the patenting of traditional indigenous medicine. The author examines the role of morality in New Zealand patent law and how this fits in with New Zealand's international obligations under the World Trade Organisation's TRIPs agreement and the Convention on Biological Diversity.

The author examines whether the patenting of Maori traditional medicine can be prevented under the morality exclusion in the Patents Act 1953 and outlines five arguments which might be used to justify various levels of intervention in the patenting process in order to protect Maori control over their traditional knowledge.

\section{INTRODUCTION}

Patent laws have generally included a "morality exclusion", a clause which allows patent authorities to exclude otherwise patentable inventions on the ground that patenting them would be contrary to morality. These morality exclusions languished almost unused for hundreds of years, but recently have been revived, mostly by European opponents of genetic engineering.

This paper was submitted in fulfilment of the LLB (Hons) requirements at Victoria University of Wellington in 2000. 
At the same time, indigenous peoples throughout the world have begun to assert that the current western intellectual property system fails to take account of their needs.

This paper considers whether the morality exclusion in the New Zealand law could help address Maori concerns.

The focus of this paper is on current patent issues in New Zealand. It is important, however, to fit the debate into the international context. There are three reasons for this. First, the impetus for demand for indigenous intellectual property rights has its roots in international moves towards self-determination. Secondly, any local solution must not conflict with New Zealand's international obligations. Thirdly, much of the debate about the function of the morality exclusion in patent law has taken place overseas.

The paper first looks briefly at international debate on patenting traditional medicine and the place of morality in the development of patent law. The second part focuses on current New Zealand patent legislation and practice, and considers how the morality exclusion in the Patents Act 1953 may affect applications relating to traditional Maori medicine, given the importance placed by the Crown on Treaty of Waitangi issues. The paper examines justifications for five possible models and assesses the advantages and disadvantages of each. Lastly, it considers how the morality exclusion fits into the future development of New Zealand patent law.

\section{THE INTERNATIONAL CONTEXT}

\section{A Traditional Medicine ${ }^{1}$}

It has been estimated that some 80 per cent of the world's population rely on traditional medicine, either because it is cheaper and/or more easily accessible, or because it is more culturally appropriate. ${ }^{2}$ Use of traditional medicine has historically been on a small local scale, either self-administered or provided by traditional healers, often without any state involvement at all. ${ }^{3}$

1 For this paper traditional medicine is taken to mean the non-clinical use of plants and herbs, usually developed following protocols developed by communities over several generations, but now including modern extracted or synthesised forms of the plant or herb.

2 World Health Organisation Fact Sheet No 134 September 1996.

3 Katrina Brown " Medicinal Plants, Indigenous Medicine and Conservation of Biodiversity in Ghana" in Timothy Swanson (ed) Intellectual Property Rights and Biodiversity Conservation (Cambridge University Press, Cambridge, 1995) 201. 
Recently, however, traditional medicine has become more mainstream even in the industrialised world, partly because of consumer interest in more "natural" alternatives to conventional medicine, and partly because new techniques of analysing and synthesising plant compounds have made it more commercially attractive. ${ }^{4}$ The World Health Organisation has recommended the integration of traditional healing into primary health care, ${ }^{5}$ and throughout the world governments have begun to consider whether and how alternative medicine should be regulated by the state. ${ }^{6}$ Part of this state regulation is the intellectual property regime and the most directly affected area is patent law.

The international debate on patenting traditional medicine basically asks two related questions; can it be patented and should it?

Discussion on the first issue involves legal questions as to whether traditional medicine can meet the basic patentability requirements of novelty and invention. Traditional medicine, by its very nature, has problems meeting both criteria. ${ }^{7}$ There has been much news coverage of this, especially with regard to the much-publicised withdrawal of the US patent for medicinal use of turmeric after opposition from Indian scientists who were able to demonstrate centuries of use. ${ }^{8}$ The conventional view is that traditional knowledge falls outside patentable items, forming part of the "common heritage of mankind". 9

This paper concerns mostly the second question, which involves not only legal issues, but also ethical, political and social considerations. Ultimately, the question as to whether traditional medicine should be patented is a question for the public and their elected representatives, although in the short term the question is effectively in the hands of the patent offices and courts.

Those who object to patenting of traditional medicine do so on the grounds that indigenous people should retain control over their traditional knowledge (including medicine) and that it should not be "expropriated", especially by large pharmaceutical

4 Brown, above n 3, 203.

5 World Health Organisation The Promotion and Development of Traditional Medicine (Geneva, 1988).

6 In New Zealand, see "Call for Strict Testing of Alternative Therapies" The Dominion, Wellington, 9 August 2000, 19

7 Darrell A Posey Traditional Resource Rights (International Union for Conservation of Nature and Natural Resources, Cambridge, (UK) 1996), 3.

8 For a comprehensive account of the turmeric case and the similar cases of neem and basmati rice see <http:/ /www.itd./org/issues/india6.htm> (last accessed 31/8/00).

9 Posey, above n 7, 5. 
companies likely to be based overseas who are unlikely to treat it with respect. ${ }^{10}$ In this context intellectual property issues have a "symbolic importance which bears no relation to the limited rights actually granted". ${ }^{11}$ Patenting the sacred Amazonian herb ayahuasca, for example, has been compared to patenting the Christian cross, ${ }^{12}$ and some activists speak of "neo-colonialism"13 or even "slavery". ${ }^{14}$

Others feel that if traditional medicine is patented indigenous peoples should receive compensation for their contributions. A recent report by the Indian government points out that "the valuable leads provided by traditional knowledge save time, money and investment" for industry and therefore "a share of benefits must accrue to creators and holders of traditional knowledge." 15

\section{B International Standardisation}

At the same time as calls for self-determination for indigenous peoples, there is a move in the opposite direction towards worldwide standardisation. As far as patents are concerned, the most relevant agreements are in the economic area, including intellectual property provisions, most notably the Agreement on Trade Related Aspects of Intellectual Property Rights (TRIPs). ${ }^{16}$ Patents are also influenced by social welfare, health and human rights (especially indigenous rights) provisions. The most recent area for international harmonisation is ecology. The Convention on Biological Diversity (CBD) ${ }^{17}$ directly

10 Darrell A Posey and Graham Dutfield Beyond Intellectual Property (International Development Research Centre, Ottawa, 1996) 7.

11 Philip W Grubb Patents for Chemicals, Pharmaceuticals and Biotechnology (Clarendon Press, Oxford, 1999) 126.

12 Glen M Wiser "PTO Rejection of the 'Ayahuasca'Patent Claim" (Center for International Environmental law, November 1999) <http://www.ciel.org/ptorejection.html> (last accessed $31 / 8 / 00)$.

13 Aroha Mead "Indigenous Rights to Land and Biological Resources" (Paper presented to Institute for International Research, 1994).

14 Graham Dutfield Biopiracy: The Slavery of the New Millennium? Surely Not (Working Group on Traditional Resource Rights, Oxford, 1998), 1.

15 Indian Government Submission to Committee on Trade and Environment / Council for Trade Related Aspects of Intellectual Property Rights, WT/CTE/W/156, July 2000, 2.

16 TRIPs (Annex 1C, Marrakesh Agreement) was signed on 15 April 1994 and came into effect on 1 January 1995. New Zealand was an original signatory.

17 The CBD was signed at the United Nations Rio Earth Summit in 1993. New Zealand was an original signatory. 
impacts on patent law. ${ }^{18}$ The importance of the CBD to the discussion is that it rejects the "common heritage" idea of traditional knowledge, ${ }^{19}$ replacing it with the principle that states have sovereignty over their own resources.

The CBD specifically refers to patents in connection with developing nations. ${ }^{20}$ This was apparently a response to a feeling that "the biodiversity rich South was providing genetic resources free to the North, which was then selling back products developed from these resources subject to exclusive patent rights. ${ }^{21 " ~ M a n y ~ f e e l ~ t h a t ~ t h e ~ C B D ~ i s ~}$ incompatible with TRIPs, ${ }^{22}$ and countries who have signed both, like New Zealand, are considering how they can best meet the requirements of both. The question is currently under review by the World Trade Organisation. ${ }^{23}$

\section{Patents and Traditional Medicine}

The traditional justification for patents is economic utilitarianism; inventors are allowed a limited monopoly over the exploitation of their invention in return for a perceived benefit to society as a whole. ${ }^{24}$ The consideration for the state's granting of patents is said to be the benefit to the state of technological and economic progress. Society benefits not only from the economic benefits of the invention itself but at the end of the protected period the knowledge is free for all to use. The limited duration of patents is thus an integral part of the system, but makes it unsuitable for protection of traditional medicine. ${ }^{25}$

Because the system is designed to encourage innovation, by providing an incentive for investment in new ideas, patent laws have always distinguished between human creations and creations of nature, between patentable inventions and unpatentable discoveries.

18 Posey and Dutfield, above n 10, 53.

19 Philip W Grubb Patents for Chemicals, Pharmaceuticals and Biotechnology (Clarendon Press Oxford, 1999) 45.

20 CBD Article 16.

21 Graham Dutfield "The World Trade Organisation, TRIPs and the Biodiversity Convention (Working Group on Traditional Resource Rights, Oxford, 1998) 1.

22 Dutfield, above $\mathrm{n} 21$.

23 See WTO Trade and Evironment News Bulletin TE/033 (July 2000) 6.

24 See Justin Hughes "The Philosophy of Intellectual Property" in Elizabeth Mensch and Alan Freeman (eds) Property Law Volume II ( Dartmouth, Aldershot (UK), 1993) 290.

25 Posey \& Dutfield above $n$ 10, 79. 
According to Cornish, "Discovery is the unearthing of causes, properties or phenomena already existing in nature; invention is the application of such knowledge to the satisfaction of social needs." ${ }^{26}$ Most patent laws in the world therefore require novelty and an inventive step. ${ }^{27}$ In the field of traditional herbal medicine, this means that the medicine itself cannot usually be patented. Patents are not available for naturally occurring plants, but they may be for a synthesised equivalent, a combination of ingredients with an unpredictable combined effect, or a process for manufacturing or standardising herbal medicine. $^{28}$ Some patent regimes specifically exclude medical treatment from patentability. 29

Many traditional medicines will be unpatentable because knowledge about their use is already in the public domain. For this reason some indigenous groups advocate "defensive publication" of traditional knowledge; for example, compilations of local use of medicinal herbs in order to prevent patenting by companies. ${ }^{30}$ Of course, to some extent this is unnecessary; even if a company patented an ointment based on active ingredients found in rangiora, for example, that would not prevent anyone plucking a leaf from a rangiora tree in the bush to apply to a cut. But many indigenous peoples are offended by the idea that their traditional medicines might be appropriated by strangers. This may be an emotional response, but that does not mean it can be disregarded.

Herbal medicine is now big business, ${ }^{31}$ and it is not surprising that pharmaceutical companies are seeking patent protection for their considerable investments in research in this area. A pharmaceutical product takes on average twelve years from initial research to sale. ${ }^{32}$ It is estimated that $25 \%$ of prescription drugs are derived from plants, and that of

26 W R Cornish Intellectual Property: Patents, Copyright, Trade Marks and Allied Rights (Sweet \& Maxwell, London 1989) 5.5.

27 Posey \& Dutfield, above n 10, 77.

28 Graeme T Laurie "Biotechnology and Intellectual Property: A Marriage of Convenience?" in Sheila McLean (ed) Contemporary Issues in Law, Medicine and Ethics (Dartmouth, Aldershot (UK), 1996) 240, 243.

29 In New Zealand claims for the treatment of humans are allowable except where the claim relates to methods of surgery or of treatment or prevention of disease. Wellcome Foundation $v$ Commissioner of Patents [1983] NZLR 385 (CA) and IPONZ Patent Examiners' Manual 4.55.

30 Dr Gerard Bodeker Indigenous Medical Knowledge, the Law and Politics of Protection (Conference paper presented at the Oxford Intellectual Research Centre, 25 January 2000).

31 According to Bodeker, above $\mathrm{n}$ 30, the World Bank estimates that by 2050 the herbal medicine market will be worth USD 3 trillion worldwide.

32 US submission to WTO TRIPs review IP/C/W/162 October 1999, 2. 
these some $75 \%$ have been developed with some input from traditional knowledge. ${ }^{33}$ These kind of figures have led to accusations of "biopiracy", accompanied by denunciations of the patent system and the whole "western" property regime. ${ }^{34}$

At the other end of the scale some indigenous peoples have attempted to use the current intellectual property system to retain control over traditional knowledge and culture. A local example is the recent attempt by some Maori to trade mark a haka. ${ }^{35}$ But traditional knowledge sits uneasily within the current intellectual property framework. Some problems indigenous peoples experience with the current intellectual property system are common to all forms of intellectual property, such as ownership and duration. Often traditional knowledge has no one "author" and it is held collectively. ${ }^{36}$ Even if there is an identifiable owner, the intellectual property system will only protect rights for a certain time. Indigenous peoples wish to protect their knowledge for perpetuity. ${ }^{37}$

The requirements for novelty and invention make patents particularly unsuitable for protecting traditional medicine because its very traditionality - the fact that it has been used for a considerable time- works against it. ${ }^{38}$ Of course, new developments in the field could be patented by indigenous peoples just as they could by anyone else. But the primary concern of Maori and other indigenous peoples is to protect their culture from expropriation and this is essentially a defensive move. ${ }^{39}$ Active attempts by indigenous peoples to patent their own knowledge are unlikely to meet this goal because of the problems outlined above. This paper therefore focuses on what might be termed "defences against patenting", that is, attempts by indigenous peoples to prevent "offensive" patents being granted. Since the objections are essentially moral, it seems sensible to consider the

33 A Gray Between the Spice of Life and the Melting Pot: Biodiversity Conservation and its Impact on Indigenous Peoples (International Working Group for Indigenous Affairs (IWGIA), Copenhagen, 1991) 4.

34 See for example Anthony Rees "Biodiversity and Intellectual Property Rights: Implications for Indigenous People of South Africa" < http://www.ihaf.com/africa/990504.html> (last accessed 31/08/00).

35 Oriwa Solomon and others from Ngati Toa submitted the application in February 1999 but withdrew the application and have not yet resubmitted it.

36 Posey and Dutfield, above n 10, 10.

37 Gray, above n $33,11$.

38 Ministry of Economic Development Maori and the Patenting of Life Form Inventions (Wellington, 1999) Part Two, 4

39 Ministry of Economic Development, above n 38, 6. 
use of the morality exclusion in patent legislation which may meet the needs of indigenous peoples within the current system.

\section{Patents and Morality}

Some question whether there is any place at all for morality in patent law since its justification is primarily economic. Critics argue that undesirable inventions can be excluded by other laws. ${ }^{40}$ Yet a morality clause has always been included in almost all patent systems. ${ }^{41}$ The relevant New Zealand provision is section 17(1) Patents Act 1953 (as amended) which states:

If it appears to the commissioner in the case of any application for a patent that the use of the invention in respect of which the application is made would be contrary to morality, the Commissioner may refuse the application.

The provision has its origin in the 1949 UK Patents Act, on which the 1953 New Zealand Patents Act was based. ${ }^{42}$ "Morality" is not defined in either Act, and the exclusion has been little used. ${ }^{43}$ The word "may" in the provision makes it clear that the power to exclude is discretionary. An example often given of items historically judged unpatentable because of immorality is contraceptives, but it seems that these were often simply excluded under the general prerogative to grant or refuse patent applications without specific reference to morality. ${ }^{44}$

In contrast the United States view of patent law has long excluded considerations of morality. ${ }^{45}$ The US Supreme Court in Diamond $v$ Chakrabarty ${ }^{46}$ famously commented that it was "without competence to entertain these arguments" 47 . This approach has its

40 Barry Hoffmaster "The Ethics of Patenting Higher Life Forms" (1988) 4 IPJ 1, 3.

41 Deryck Beyleveld and Roger Brownsword "Patenting Human Genes: Legality, Morality and Human Rights" in JW Harris (ed) Property Problems : From Genes to Pension Funds (Institute of Advanced Legal Studies, London, 1997) 10.

42 New Zealand Commentary on Halsbury's Laws of England (4 ed, Butterworths, Wellington, 1985) Chapter 117, Patents and Inventions, para C302, 4.

43 Grubb, above n 11, 56.

44 Grubb, above n 11, 58.

45 Stephen A Bent, Richard L Schwaab, David G Conlin and Donald D Jeffery Intellectual Property Rights in Biotechnology Worldwide (Macmillan Stockton Press, New York, 1987) 102.

46 Diamond v Chakrabarty (1980) 447 US 303.

47 Diamond $v$ Chakrabarty, above n 46, 307. 
supporters outside the United States. Nott argues that the European Patent Convention should drop all reference to morality because it is "irrelevant and counterproductive". ${ }^{4}$ When the intellectual property law was being reviewed in 1993 the New Zealand Ministry of Commerce lobbied to drop the morality exclusion because it felt that "inventions contrary to law or morality can be controlled by the law against which the invention is contrary". ${ }^{49}$ It has to be said that this seems to assume that immorality and illegality are the same thing, which is clearly not the case. ${ }^{50}$

In the event a reference to morality was retained in the 1994 amendment, partly, it seems, in response to Maori concerns. ${ }^{51}$ It should be noted that the amendment went through Parliament hastily with a package of other reforms designed to give effect to New Zealand's obligations to the World Trade Organisation following the Uruguay Round and Parliamentary debate on the patents provisions was severely limited. ${ }^{52}$ In any case, it was expected at the time that there would shortly be a wholesale rewriting of New Zealand intellectual property law. ${ }^{53}$

The TRIPs agreement, significantly, retains the idea of morality (and the similar "ordre public") despite US opposition. ${ }^{54}$ The relevant provision is Article 27.2 which states:

Members may exclude from patentability inventions, the prevention of which within their territory is necessary to protect ordre public or morality, including to protect human, animal or plant life or health or to avoid serious prejudice to the environment.

The concept seems to have been included at the insistence of European nations, who modelled the TRIPs morality clause on the European Patent Convention (EPC), section

R Nott "The European Biotech Directive - An End in Sight? (Reprise)" Patent World, September $1994,5,6$.

49 Ministry of Commerce Reform of the Patents Act 1953 Proposed Recommendations (Wellington, 1992) 8.

50 For an interesting discussion of the difference between law and morality see Ronald Dworkin Taking Rights Seriously (Harvard University Press, 1978).

51 (29 November 1994) 517 NZPD 5224-5225.

52 (29 November 1994) 517 NZPD 5224-5225.

53 Rt Hon Don McKinnon above n 51, 5225.

54 Richard Ford "Morality of Biotech Patents: Differing Legal Obligations in Europe?" [1997] EIPR 315. 
53(a) ${ }^{55}$ which excludes from patentability inventions "contrary to ordre public or morality". Neither "morality" nor "ordre public" is defined in either provision, but the European Patent Office (EPO) guidelines offer some guidance. They state that "the purpose of these exclusions is to prevent the patenting of inventions likely to induce public disorder or riot or to lead to generally offensive or criminal behaviour". The guidelines propose as a test that "the general public would regard the invention as so abhorrent that the grant of patent rights would be inconceivable". ${ }^{56}$ This seems to set a very high standard; the original drafters apparently intended that it should be used exceptionally. ${ }^{57}$ In recent times, however, a different test seems to have been preferred, at least in the context of biotechnology. Faced with complex arguments and widespread public concern about genetic engineering, the EPO adopted a balancing test approach in the "Oncomouse" application. ${ }^{58}$ This approach is reflected in the recent European Community Biotechnology Patenting Directive, ${ }^{59}$ which includes a (non-exhaustive) list of immoral inventions "likely to cause animal suffering without any substantial medical benefit to man or animal". ${ }^{60}$ While decisions of the European Patent Office are obviously not binding in New Zealand, it is submitted that the EPO's approach is influential for several reasons. First, the wording of Article 53(a), which is not part of New Zealand law, is similar to TRIPs Article 27.2, which is. Secondly, decisions of the English courts are persuasive in New Zealand, and as the United Kingdom is part of the EPC, EPO decisions will affect English law. Also, most recent decisions about morality have come from the EPO which is generally highly respected. ${ }^{61}$ While so far this "balancing" test seems to have been applied only in the controversial biotechnology area, it might be seen as a recognition that patenting issues are becoming more complicated. This is true not only in the biotechnology area, but arguably in all areas where the notion of "public good" is unclear, and this could include indigenous issues.

55 Michael Blakeney Trade Related Aspects of Intellectual Property Rights: A Concise Guide to the TRIPs Agreement (Sweet and Maxwell, London, 1996) para 1.03.

56 EPO Guidelines C IV 3.1.

57 Beyleveld and Brownsword, above n 41, 10.

58 Harvard/Transgenic Mouse T 1990 (OJ 1990, 476).

59 European Parliament Directive 98/44.

60 Above n 59, article 16.

61 Grubb, above n 11, 262. 


\section{E Criticisms of the Morality Exclusion}

Critics of morality clauses argue that this weighing of complex ethical arguments should not be left to patent office examiners, who are not trained in the area and do not have the time -or, perhaps, the desire- to take wider policy issues into account. The British Biotechnology Group recently asserted that "the morality exclusion places an unfair burden on patent offices." ${ }^{62}$ Such complex issues, according to critics, are better dealt with by the legislature. They argue that it is difficult for patent offices and courts to know which test to apply; the concept of morality is subjective and difficult to define and changes not only with place and time, but also within any one society at any time. Critics of the morality exclusion also argue that the standard of debate in recent EPO cases has been emotive and, some argue, misguided; ${ }^{63}$ those who use it really object to the research behind the patent and confuse patent issues with safety and animal welfare issues which could be better regulated in other ways. ${ }^{64}$ As a way of stopping morally repugnant research it is ineffective, as even if opponents succeed in preventing patenting of an invention it can still be used and arguably it is easier to regulate through the patent system, which requires disclosure. ${ }^{65}$

\section{F Advantages of the Morality Exclusion}

On the other hand, the morality clause does have its supporters Some say that if the purpose of the morality exclusion is to protect public morality, the patent examiners as members of the public are as well-qualified as anyone else to judge moral issues. ${ }^{66}$ Any subjectivity and failings of patent examiners are to some extent balanced by the possibility of appealing against their decisions. The existence of a morality exclusion is also said to ensure, however imperfectly, that there is some mechanism for public debate on important subjects, which might not otherwise be addressed. For concerned groups the patent process is a relatively cheap and high-profile way to get their concerns aired. It could also be stated that all law changes with time, and morality is found in all areas of the law. Just because other areas of the law need reform too does not mean the patent process cannot play a part.

62 Grubb, above n 11, 256.

63 Shelley A Rowland and James A Piper "Patents and Biotechnology" <http://www.piperpat.co.nz/resource/life.html> (Last accessed 31 August 2000).

65 Hoffmaster, above $\mathrm{n} 40,3$.

66 Grubb, above n 11, 78. 


\section{MORALITY AND TRADITIONAL MAORI MEDICINE}

\section{A Introduction}

New Zealand contains about 100 native plants with known medicinal properties. ${ }^{67}$ Use of these by Maori is well documented, although there is some uncertainty about to what extent Maori used medicinal plants internally before the arrival of Europeans. ${ }^{68}$

Seventy-four percent of New Zealanders are believed to use herbal or other "natural" medicines, ${ }^{69}$ although few of these are derived from native plants. ${ }^{70}$ Several small local companies have begun selling remedies based on native plants. ${ }^{71}$ None of these is at present patented. This illustrates the point that traditional medicine can be exploited commercially without being patented.

Along with many indigenous peoples, some Maori claim that the very idea of "owning" traditional knowledge of any kind is offensive and call for a wholesale rewriting of New Zealand intellectual property laws to take account of indigenous concerns. ${ }^{72}$ Even if it was agreed that this was desirable, however, it would take a long time to achieve. In the meantime, the existing morality exclusion could be useful to Maori (and others) who wish to prevent patenting of traditional medicine. It does not seem so far to have been raised as an issue with relation to traditional medicine.

As we have seen, the patent system is administered by the state. Public, including Maori, can influence the process directly, by lodging objections or questioning decisions in the courts through the process of judicial review. (That the latter can have a huge impact is illustrated by the NZ Maori Council Case). ${ }^{73}$ They can also influence the way the law

67 S G Brooker, R C Cambie and R C Cooper New Zealand Medicinal Plants (Heinemann, Auckland, 1987) 19.

68 Brooker, Cambie and Cooper, above n 67, 39-42.

69 NZ Charter of Health Practitioners, New Zealand Health Survey (Wellington, 1997).

70 The product list of New Zealand's largest producer of herbal supplements, Thompson Nutrition Ltd, contains no products based on New Zealand native plants.

71 For example, Living Nature of Kerikeri produces a range of ointments based on manuka oil.

72 See for example the Mataatua Declaration on Cultural and Intellectual Property Rights of Indigenous Peoples at <http://www.tpk.govt.nz/mataatua/mataengl.htm> (Last accessed $31 / 8 / 2000)$.

73 NZ Maori Council v Attorney General [1983] 2 NZLR 142. For a critical discussion of the impact of the case, see David Round Truth or Treaty? (Canterbury University Press, Christchurch, 1998) 1267. 
develops more indirectly, through lobbying and general "consciousness-raising", and through the election process.

Maori have a uniquely strong influence on the State because of the existence of the Treaty of Waitangi and the widely-held view that it obliges a "partnership" approach between the Crown and Maori. ${ }^{74}$ Article II of the Treaty is said to give Maori tino rangatiratanga (stewardship) over all taonga. According to some Maori, this gives guardianship rights over all native flora and fauna, including associated intellectual property rights. This is the basis for the Wai 262 claim currently before the Waitangi Tribunal. ${ }^{75}$ The Ministry of Economic Development acknowledges that "in terms of the Treaty of Waitangi, patents are granted by the Crown and therefore the Treaty relationship between the Crown and Maori is relevant to all aspects of the patent process". ${ }^{76}$

In New Zealand, the patent system is administered by the Intellectual Property Office of New Zealand (IPONZ), part of the Ministry of Economic Development (formerly Ministry of Commerce).

When a patent is submitted it is examined. In principle IPONZ has the right to refuse patent applications if their use would be contrary to law or morality. ${ }^{77}$ In practice this is virtually never used. The patent application, once it has been accepted, is then published in the IPONZ Journal and interested parties have three months to lodge an objection. The grounds for this are set out in the Patents Act. ${ }^{78}$ They do not include a reference to morality. In any case, the problem here would be for Maori to establish the necessary standing. After a patent has been granted a third party can apply to have the patent revoked. In practice, this process is more important than opposition. The grounds for revocation are essentially the same as for opposition. ${ }^{79}$ It seems therefore that morality is unlikely to be raised successfully as a ground for either. ${ }^{80}$ This should be contrasted with

74 This view has recently been repeated by Minister of Health Annette King. See "Taking the Treaty Too Far" The Dominion, Wellington, 30 August 2000, 10.

75 WAI-262, First Amended Statement of Claim, 10 September 1997, para 2.2.

76 Ministry of Economic Development Maori and the Patenting of Life Form Inventions (Wellington, 2000) 2. IPONZ Information Booklet: Patents Application and Grant (Lower Hutt, 1998).

78 Patents Act 1953, s 21.

80 However, prior use is a potentially useful ground for opposition and revocation: Sections 21 (1) (d) and 41 (1) (d). 
the European legislation which allows as a ground of opposition ${ }^{81}$ non-compliance with Articles 52 to 57 , which includes the morality exclusion. ${ }^{82}$ It seems that New Zealand is unlikely under the current legislation to see colourful opposition proceedings as have happened before the EPO Opposition Board.

This leaves several opportunities for morality to be used under the current New Zealand law. First, Maori could encourage the development of guidelines for IPONZ officers on the use of the morality exclusion which include a Maori perspective. ${ }^{83}$ Secondly, after a patent has been granted Maori (with sufficient standing) could apply for judicial review of the exercise of IPONZ's discretion in granting a patent, citing the Treaty of Waitangi as a relevant consideration that should be considered. Of course, litigation is expensive and time-consuming, and many Maori feel that they should not need to resort to the courts to enforce their rights. ${ }^{84}$

\section{B Is Patenting of Maori Traditional Medicine Contrary to Morality?}

Possible arguments for excluding patents for traditional Maori medicines on the grounds of immorality may be summarised as follows;

(1) It is immoral to patent any traditional medicine at all.

(2) It is immoral for non-Maori to patent traditional Maori medicine.

(3) It is immoral for foreign individuals or corporations to patent traditional Maori medicine.

(4) It is immoral to patent traditional Maori medicine without Maori compensation.

(5) It is immoral to patent traditional Maori medicine without Maori consultation.

It should be noted that some of these are contradictory, in that items 3 and 4 at least seek economic advantage for Maori while item 1 rejects completely the concept of economic rights over nature. I now consider each assertion in turn. What are the justifications behind each assertion? How might they work in practice?

$81 \quad$ EPC, art 100.

82 EPC, art 53(a).

83 IPONZ is currently working with Maori to establish clearer guidelines. See IPONZ Patenting of Biotechnoligical Inventions (Lower Hutt, 1999).

84 Maori lawyer Moana Jackson has recently commented that "The litigation has got to stop" (Interview with Kim Hill, National Radio, 30 August 2000). 


\section{It is immoral to patent traditional medicine at all}

There are two possible rationales behind this assertion. The first is that that, following the "common heritage" idea, traditional knowledge should be freely available to all. The second rationale is that ownership rights over nature are repugnant from a spiritual or ethical viewpoint. This is really an argument against the whole Western property system. According to Tania Tetitaha "[o]wnership is inconsistent with the compartmentalisation of man from nature, a logical derivation of the 'self: other' or 'nature : man' dichotomy which was foreign to the Maori world view." 85

The Maori world view is said to include: 86

[A] sacred regard for the whole of nature and its resources as being gifts from the gods ... a sense of responsibility for these gifts as the appointed stewards ... a sense of commitment to safeguard all of nature's resources as taonga for future generations.

To put this idea fully into practice could involve adding products or processes connected with native plants as an unpatentable exclusion to the Patents Act. The TRIPs agreement allows member states to make exclusions of this kind, ${ }^{87}$ and some argue that the CBD obliges them to use such exceptions to protect biodiversity. ${ }^{88}$ The problem with the biodiversity approach is that it is necessary to distinguish the plants themselves from intellectual property rights over them. The recently passed Costa Rican Ley de Biodiversidad which attempts to reconcile Costa Rica's obligations under TRIPs and the CBD, does this explicitly. It states that while the resources themselves may be owned by individuals or the state, the properties of these resources can be owned by nobody. ${ }^{89}$ Preventing patenting, however, will not prevent exploitation, although arguably patenting encourages culling of native plants.

85 Tania Tetitaha The Interrelationship between Humans, Plants, Animals and Gods (Paper presented to the Talking Technology Trust, Wellington, 1997) 7.

86 Bev James The Maori Relationship with the Environment (Wellington Regional Council, 1993) 8.

87 TRIPs, art 27.2.

88 See, for example, Erica Irene Daes, Some Observations and Curent Developments on the Protection of Intellectual Property of Indigenous Peoples, (address to the Roundtable on Intellectual Property and Traditional Knowledge, WIPO, Geneva, 23 July 1998) WIPO/INDIP/RT/98/1 <http://www.wipo.org/eng/meetings/1998/indip/daes.htm> (last accessed 14 Jan 2001).

89 Graham Dutfield The Costa Rica Biodiversity Law: A Brief Summary (Programme for Traditional Resource Rights, Oxford, 1998). 
The other problem here is the meaning of "contrary to morality". If we take the approach that it means "objectionable to the majority of society" (what Beyleveld and Brownsword call "the yuk factor" ${ }^{10}$ ), then the patenting of traditional Maori medicine is unlikely to meet the test. There is no one Maori viewpoint - as Maui Solomon points out, many Maori are in favour of commercial enterprise. ${ }^{91}$ Even if patenting were highly objectionable to all Maori, they are still in the minority of New Zealand's population. On the other hand, if the "balancing test" approach were used, a strongly felt opinion by a small sector of society might be felt to outweigh the supposed advantages.

\section{It is immoral for non-Maori to patent traditional Maori medicine}

The rationale behind this is that traditional knowledge is tapu, ${ }^{92}$ and should only be used by certain individuals, or in certain ways (such as in combination with prayers). ${ }^{93}$ In practice this is difficult to achieve through the patent system or indeed by any law which might be seen as interfering with freedoms of religion. It seems that voluntary requests would be the only way to achieve this goal. In any case, secret knowledge seems to contradict the whole rationale of the patent system, which allows knowledge to revert to the public domain. Te Puni Kokiri also identifies a risk of "overprotection". 94 TRIPs allows member states to place restrictions on the use of patents, but any restrictions have to be reasonable. Article 30 states that:

Members may provide limited exceptions to the exclusive rights conferred by a patent, provided that such exceptions do not unreasonably conflict with a normal exploitation of the patent and do not unreasonably prejudice the legitimate interests of the patent holder, taking account of the legitimate interests of third parties.

Such a view of exclusion is unlikely to appeal politically to the general population.

90 Beylereld and Brownsword, above, n 41, 21.

91 According to Solomon, "Maori are not opposed to development and advancement. In fact their own culture fully embraced and was highly adaptive to new technology. But Maori seek a greater degree of control". Maui Solomon Maori Cultural and Intellectual Property (Speech to Indigenous IPR Conference, University of British Columbia, 24 February 2000).

92 E Best The Maori School of Learning (Government Printer, Wellington, 1959) 29.

See Brooker, above n 67, 32 - 42, for accounts of traditional practice of Maori tohunga.

94 Te Puni Kokiri Nga Taonga Tuku Iho No Nga Tupuna / Maori Genetic, Cultural and Intellectual Property Rights (Wellington, 1994) para 5. 


\section{It is immoral for foreigners to patent traditional Maori medicine}

This argument has more of an economic justification, being an argument to retain the economic benefits in New Zealand so as to benefit both Maori and non-Maori. Taken to the extreme, this would probably mean patents being held by the state. This approach is favoured in South America ${ }^{95}$ but is unlikely to appeal in free-market New Zealand, although the Government apparently sees itself as a "guardian/kaitiaki of cultural heritage", including intellectual property rights. ${ }^{96}$ Even if the government held New Zealand patents on behalf of New Zealanders, however, it would be unable to prevent products derived from native plants being patented overseas. The position could also be difficult to defend where related plants with the same active agreement are found elsewhere. ${ }^{97}$ The most serious impediment, however, is that reserving patents for New Zealanders would seem to conflict with New Zealand's WTO commitments. TRIPs Article 27.1 states:

Patent rights shall be available and patent rights enjoyable without discrimination as to the place of invention, the field of technology and whether products are imported or locally produced.

At the same time as TRIPs was agreed, the WTO put in place a new binding disputes procedure. The implication of this is that if another state took New Zealand to the Dispute Settlements Board of the WTO and won, New Zealand would either have to comply or risk sanctions. ${ }^{98}$

\section{It is immoral to patent traditional Maori medicine without Maori compensation}

The justification for this is that patents are supposed to reward labour and so the prior labour of Maori in identifying uses for native plants and guarding them should be rewarded. The difficulty with this justification in the New Zealand context is that often

95 Dutfield, above $\mathrm{n} 89,1$.

96 Ministry for Culture and Heritage Government's Role in the Cultural Sector : A Survey of the Issues (Wellington, 1998) available at <http://cultureandheritage.govt.nz/publications/govt_role_in_ cult_sect/6.html> (last accessed 28 Aug 2000).

97 For example the active ingredient in puriri is found in many related species of the vitex genus in Malaysia, Indonesia, China, Fiji, India and Europe and medicinal use has been recorded in all these areas: Brooker, above $\mathrm{n}$ 66, 236.

98 World Trade Organisation Trading into the Future (Geneva, 1999) 38-42. 
non-Maori seem to have made significant contributions to the development and collation of Maori medicine. ${ }^{99}$

Under this model anyone successful in gaining a patent would be granted it on condition that they made suitable licensing or royalty arrangements with Maori. Under TRIPs Article 30, as noted above, any restrictions have to be "reasonable".

The main practical problem would be identify to which Maori body royalties should be paid. Also, presumably it would raise the price of any product successfully patented.

\section{It is immoral to patent traditional Maori medicine without Maori consultation}

The rationale for this is that Maori should be able to signal offensive uses and should be consulted by IPONZ in accordance with the Crown's obligations under the Treaty of Waitangi. How persuasive any objection from Maori would, or should, be is open to discussion, but on the plus side there are already models for Maori consultation which could be adapted without much difficulty.

Maori are often represented on state bodies, usually those that concern environmental issues, but lately social bodies too such as community health boards. ${ }^{100}$ It must be noted, however, that in these cases the legislation concerned specifically addresses Treaty issues. ${ }^{101}$ The Patents Act does not. This is not surprising, given its age and origin. When the Act was amended in 1994 there was some suggestion of adding Treaty of Waitangi issues, but it was felt that this would better be addressed in the proposed Intellectual Property Bill. ${ }^{102}$

It can be argued that a stage should be added to the patent application requiring consultation with Maori, for example, adding a Maori committee (as in the Resource Management process). ${ }^{103}$ The Main Trade Marks Focus Group proposed a similar consultative committee stage in its 1997 discussion paper. ${ }^{104}$ Some will argue that its recommendations should not be binding; although Maori views may be strongly held, they do not represent the views of New Zealanders as a whole and if the "public good" is

99 Brooker, above n 67, 32-42.

100 For a criticism of this approach see "Treaty Clause Danger Ahead" The Dominion, Wellington, 15 August 2000, 8 .

101 See, for example, the Hazardous and New Organisms Act, s 8.

102 Rt Hon Don McKinnon, above n 51, 5225.

103 For an overview of the process, see <http://www.ermanz.govt.nz>.

104 Ministry of Commerce Maori and Trade Marks: a Discussion Paper (Wellington, 1997) 27. 
the base principle, then a patent should not be excluded as immoral just because a certain part of society finds it objectionable. ${ }^{105}$ But if the recommendations are not binding some will dismissed the consultation process as mere "window-dressing."

\section{The Future of New Zealand Patent Law}

Assuming that New Zealanders decide that they do wish to address Maori concerns this could be achieved in three stages, each requiring various degrees of reform.

\section{Total reform}

At the most drastic extreme, New Zealand could completely re-write its intellectual property law and create a completely new sui generis system for protecting traditional Maori knowledge of all sorts, such as the model proposed by Te Puni Kokiri. ${ }^{106}$ Many indigenous groups throughout the world have called for this, including Maori. ${ }^{107}$ It has the advantage of addressing the whole problem of traditional intellectual and cultural property rights at once. If sufficient time were taken for discussion this would be the most complete solution, but it would take a long time.

In reality New Zealand is unlikely to take this path alone. Impetus for this kind of change has come from various international organisations and there is no shortage of proposed international models. ${ }^{108}$

\section{Patent Act reform}

New Zealand could reform its patent law to take account of Maori concerns. For example, a clause could be added to make it explicit that the Patents Act must be interpreted in line with the Treaty of Waitangi. The morality exclusion could be rewritten to exclude specifically matters offensive to Maori. The opposition and revocation grounds could be rewritten to include offensiveness to Maori or the wider "contrary to morality" as a ground for application. Compulsory consultation with Maori could be added. Perhaps a Maori committee could be added as in the Hazardous and New Organisms Act. No doubt all this would add considerably to the workload of patent offices and possibly would make patent prosecution a slower and more costly process. Critics would argue that reform of the Patents Act alone is an unsatisfactorily piecemeal approach and a more

105 The Maori Trade Marks Focus Group suggested that the word "significant" should be removed, or re-defined so that it is "not limited to a large number". Ministry of Commerce, above n 104, 23.

106 Te Puni Kokiri, above n 94.

107 Mataatua Declaration, above n 72.

108 Several models are considered in detail in Posey, above n 7. 
radical overhaul of all legislation is needed. On the other hand, relatively large changes could be made with little reform of the law and it would lead to greater certainty. Reform of the Patents Act is not likely to happen in the near future, partly because the government already has a heavy legislative load, but mostly because the government has shelved any reform until the Waitangi Tribunal reports back on the Wai 262 claim. It would probably now be wise to wait also for the report of the Royal Commission on Genetic Engineering. ${ }^{109}$ Both address Maori intellectual property concerns.

\section{Better use of the current morality provision}

It seems unlikely, therefore, that either of the above two reforms are likely. This leaves us with the current Act. Maori can use the general novelty and invention requirements and the morality exclusion, as outlined above. Perhaps this could be combined with clearer guidelines for patent examiners as to how the morality exclusion should be applied in practice. This could be combined with voluntary consultation with Maori. For example, the IPONZ forms to be used when applying for a patent could draw applicants' attention to the possibility of consulting with Maori, and suggest ways in which this could be done. This could be combined with other regulations and protocols outside the patenting process, such as ethical guidelines for researchers. ${ }^{110}$ The advantage of this is that it requires no change to the law at all and it is likely to be acceptable to the non-Maori public. The disadvantage is again that it addresses only a small part of Maori concern - and voluntary protocols can be ignored.

\section{CONCLUSION}

Maori concerns about the patent system need to be addressed. Ultimately, if Parliament decides that it is appropriate, the most complete solution would be to create a sui generis system specifically designed to accommodate traditional Maori knowledge, including medicine. A less drastic, but less complete solution would be to reform the Patents Act 1953 to address Maori concerns.

In the meantime, the morality exclusion in the current Act could go some way to meeting Maori concerns without the need for reform. Any use must be practically workable, politically acceptable and consistent with New Zealand's international

109 The Wai 262 claimants have recently been granted "interested person" status by the Commission. For a list of approved interested persons see <http://www.gmcommission.govt.nz> (last accessed 14 Jan 2001).

110 See, for example, International Society of Ethnobiology Code of Ethics at <http:// users.ox.ac.uk/ wgtrr/isecode.htm> (last accessed 11 Nov 2000). 
obligations. In practice the provisions for opposition and revocation are unsuitable, so this means either lobbying to have the patent examiners take more notice of the Maori view of morality, or applying for judicial review. 
